\title{
Comparison of Some Physical and Mechanical Properties of Waterborne Acrylic Coating Systems Containing Commercial UV Absorbers and Tree Bark Extracts
}

\author{
Özlem ÖZGENÇ ${ }^{1 *}$, Süleyman KUŞTAŞ ${ }^{1} \oplus$, Sefa DURMAZ²@ \\ ${ }^{1}$ Karadeniz Technical University, Faculty of Forestry, Department of Forest Industrial Engineering, \\ Trabzon, TURKEY \\ ${ }^{2}$ Muğla Sitkı Koçman University, Department of Woodworking Industrial Engineering, Mugla, TURKEY \\ *Corresponding author: oozgenc@ktu.edu.tr
}

Received Date: 14.01.2019

Accepted Date: 02.09.2019

\section{Abstract}

Aim of study: The aim of this study was to compare solid content, dry film thickness, and adhesion strength of different tree bark extract based and a commercial UV absorber.

Materials and methods: Waterborne acrylic-based coating systems containing 5 different tree bark extracts (maritime pine, Calabrian pine, black pine, alder, fir) and a commercial UV absorber (Tinuvin 400 DW) were applied to 2 different wood species; Scots pine (Pinus sylvestris L.) and beech (Fagus orientalis L.). The dry-film thicknesses of the coatings were measured with light microscopy. The adhesion strength of the coatings was determined to investigate the bonding ability of the coatings with wood surfaces. The solid contents of the coatings were also determined.

Main results: Permeability is an important parameter for dry-film thickness and adhesion strength. Wood species also influenced the dry-film thickness as well as adhesion strength. The dry-film thicknesses of the coatings containing bark extracts were higher than those with commercial UV absorbers. Similarly, the solid content of the coating containing maritime pine bark extract was found to be the highest.

Highlights: The dry-film thickness and adhesion strength of waterborne acrylic coatings on wood substrate seem to be affected by addition of tree bark extracts.

Keywords: Acrylic Coating, Adhesion Strength, Dry Film Thickness, Tree Bark Extract, Pull-Off Test

Ticari UV Absorber ve Ağaç Kabuk Ektraktı İçeren Su Bazlı

\section{Akrilik Yüzey Koruyucu Sistemlerin Bazı Fiziksel ve Mekanik Özelliklerinin Karşılaştırılması}

Öz

Çalışmanın amacı: Bu çalışmanın amacı su bazlı yüzey koruyucu sistemlerin bazı fiziksel ve mekanik özelliklerinin incelenmesidir.

Materyal ve yöntem: 5 farklı ağaç türü (göknar, kızılçam, karaçam, kızılağaç, sahil çamı) ve UV absorber (Tinuvin 400 DW) içeren su bazlı akrilik reçine yüzey koruyucu sistemleri 2 farklı ağaç türüne; sarıçam (Pinus sylvestris L.) ve kayın (Fagus orientalis L.) uygulanmıştır. Kuru film kalınlıkları 1şık mikroskobu ile ölçülmüştür. Yüzey koruyucuların yüzey ile bağlanma yeteneklerini incelemek amacıyla yapışma direnci belirlenmiştir. Ayrıca yüzey koruyucuların katı madde miktarları da belirlenmiştir.

Sonuçlar: Geçirgenlik, kuru film kalınlığı ve adezyon direnci için önemli bir parametredir. Aynı zamanda odun türü de kuru film kalınlığı ve adezyon direncini etkilemektedir. Kabuk ekstraktı içeren yüzey koruyucuların kuru film kalınlıkları ticari UV absorver içerenlerden daha yüksek bulunmuştur. Benzer şekilde, en yüksek katı madde miktarı sahil çamı ekstraktı içeren yüzey koruyucuda bulunmuştur.

Önemli vurgular: Su bazlı akrilik yüzey maddelerinin kuru film kalınlığı ve adezyon direncinin ahşap malzemeler üzerinde önemli etkileri vardır.

Anahtar Kelimeler: Akrilik Yüzey Maddesi, Yapışma Direnci, Kuru Film Kalınlığı, Ağaç Kabuk Ekstraktı, Çekme Testi 


\section{Introduction}

The physical and chemical changes occur on wood surfaces that are exposed to outdoor conditions (Kılıç \& Hafizoğlu, 2007). Light (UV, IR), humidity (rain, snow) and mechanical forces (wind, sand, soot) alter the wood surface adversely and result in cracks, surface roughness, as well as discoloration (Feist \& Hon, 1984; Williams, 2005). Biological and physical factors already cause modifications in the main components of wood, especially cellulose, hemicellulose and lignin. On the other hand, extractives are influenced relatively less during the photodegradation process. However, their concentration, color and odor change affects the non-mechanical properties of wood (Feist, 1990; Pandey, 2005).

Different methods have been preferred to restrain the changes on wood surfaces during the service life in the outdoors and also increase durability of wooden materials (Williams, 2005). These methods (paint, varnish, polish, water repellent, etc.) have been applied prevent contact between water and UV light and the wood surface. Moreover, other than these, alternative products have been offered to market in recent years (Ozgenç, Hiziroglu \& Yildiz, 2012; Decker, Masson \& Schwalm, 2004; Evans \& Chowdhury, 2010).

Tree bark extracts have been evaluated for their organic UV absorbance values due to their high antioxidant effects. Kocaefe and Saha (2012) compared the effects of acrylic polyurethane-based coatings containing bark extract, lignin stabilizer, UV absorber and hindered amine light stabilizer (HALS). The bark extracts and lignin stabilizer were found to provide the highest photo-stabilization effect on heat-treated wood surfaces. Saha, Kocaefe, Boluk and Pichette (2011) reported that bark extract and lignin stabilizers (alone or in combination) in acrylic polyurethanebased coatings increased resistance against outdoor conditions. Bark extracts also enhance color stabilization of wood samples. The combination of 2-hydroxy-4(2,3epoxypropoxy)-benzophenone (HEPBP) as UV absorbent and epoxy functional soybean oil increased color stabilization in outdoor conditions compared to only UV absorbent (HEPBP). Moreover, combination of UV absorbent (HEPBP) and epoxy functional soybean oil provided protection against degradation factors in outdoor conditions (Philip \& Mohammed, 2010; Olsson et al., 2012;). Saha, Kocaefe, Krause, Boluk \& Pichette, (2013) investigated the weathering performance of polyurethane-based coatings containing three different UV stabilizers. It was reported that coatings containing bark extracts with or without lignin stabilizers hindered photo-degradation. In another study, wood surface was pre-treated with mimosa (Acacia mollissima) and quebracho (Schniopsis lorentzii) bark extracts before applying polyurethane, cellulosic and waterbased varnishes (Yalcin \& Ceylan, 2017). It was reported that pretreatment with bark extracts decreased the adhesion strength of coatings.

Dry-film thickness and adhesion strength influence the weathering performance of acrylic-based coatings. This study investigates the adhesion strength of waterborne acrylic-based coatings containing tree bark extracts and commercial UV absorbents (Tinuvin 400 DW). For this purpose, five different tree species (maritime pine, calabrian pine, black pine, alder, fir) were selected and their bark extracts were obtained with alcohol-benzene. The coating systems were applied to two different wood species; Scots pine (Pinus sylvestris L.) and beech (Fagus orientalis L.). The dry-film thickness of the coatings was examined by light microscopy. The results were compared to adhesion strength values to evaluate the effects of the bark extracts. The solid content of coatings was also determined.

\section{Material and Methods \\ Wood Materials}

In this study, defect-free samples of scots pine (Pinus sylvestris L.) and oriental beech (Fagus orientalis L.) tree species were selected. The wood samples were prepared with dimensions of $150 \mathrm{~mm}$ (longitudinal) by $70 \mathrm{~mm}$ (tangential) by $20 \mathrm{~mm}$ (radial) for artificial weathering.

\section{Tree Barks}

The barks were peeled off from the 20-30year-old alder (Alnus glutinosa), calabrian pine (Pinus brutia), maritime pine (Pinus 
pinaster), black pine (Pinus nigra) and fir (Abies nordmanniana L.) trees that were cut down in the Black Sea Region in northern Turkey. The preparation and chopping processes of the tree barks were implemented according to the TAPPI $\mathrm{T} 257 \mathrm{~cm}-12$ and TAPPI T $264 \mathrm{~cm}-07$ standards of extraction. Tree barks were air-dried at room temperature $\left(23{ }^{\circ} \mathrm{C}, 65 \%\right.$ relative humidity) and then grinded by using a laboratory scale Willey mill to obtain 40 to 60 -mesh wood powder.

\section{Bark Extraction}

The bark powders were extracted in a Soxhlet extractor to obtain extractives. The bark powder ( $25 \mathrm{~g}$ for each) was soaked in 300 $\mathrm{mL}$ of ethyl alcohol: benzene mixture (1:2 $\mathrm{v} / \mathrm{v})$. The solvents from each extract were removed by using a rotary evaporator at $50{ }^{\circ} \mathrm{C}$ and stored in sealed flasks at $4{ }^{\circ} \mathrm{C}$ until use.

\section{Preparation of Coating Systems}

Six different wood coating systems were obtained using acrylic resin, binder, diluent, antifoam, pure water, bark extract or UV absorber (Table 1). " Tinuvin ${ }^{\circledR}$ 400-DW ", which is used as a commercial UV absorber, is a product of BASF. Tinuvin ${ }^{\circledR} 400-\mathrm{DW}$ is an aqueous white to light beige liquid dispersion of a 2-hydroxy-phenyl-s-triazine (HPT) UV absorber (UVA) (https://www.ulprospector.com/en/na/Coatin gs/Detail/479/741631/Tinuvin-400-DW-N).

The coatings containing the commercial UV absorber were regarded as a control and compared to the coatings containing bark extracts.

Variation code:

A: Water borne acrylic resin-based coating containing fir extract

B: Water borne acrylic resin-based coating containing alder extract

C: Water borne acrylic resin-based coating containing calabrian extract

D: Water borne acrylic resin-based coating containing maritime pine extract

E: Water borne acrylic resin-based coating containing black pine extract
F: Water borne acrylic resin-based coating containing UV absorber

Table 1. Acrylic resin-based surface system formulation components (\%).

\begin{tabular}{lccc}
\hline No & Components & $\begin{array}{c}\text { Formulation } \\
\text { containing } \\
\text { bark extract }\end{array}$ & $\begin{array}{c}\text { Formulation } \\
\text { containing } \\
\text { UV } \\
\text { absorber }\end{array}$ \\
\hline 1 & Acrylic resin & 72.5 & 72.5 \\
2 & Diluted water & 18.88 & 20.88 \\
3 & Coalescent & 0.67 & 0.67 \\
4 & Defoamer & 1.0 & 1.0 \\
5 & Thickener & 0.6 & 0.6 \\
6 & Thickener & 1.3 & 1.3 \\
7 & Bark extract & 5.0 & - \\
8 & UV absorber & - & 3.0 \\
9 & Ammonia & 0.05 & 0.05 \\
\hline
\end{tabular}

Application of coating systems on the wood surface

The water-based wood preservative Induline SW 900 was applied as a primer layer to the side and front of the $120 \times 70 \times 10 \mathrm{~mm}^{3}$ wood samples for the artificial weathering test. The coating systems were applied in two layers using a brush with 24-hour intervals. The coated wood samples were conditioned for 2 weeks at $20^{\circ} \mathrm{C}$ and $65 \pm 5 \%$ relative humidity.

\section{Determination of Dry Film Thickness and Solid Contents}

1-gr samples were taken from the acrylicbased coatings and dried at $103{ }^{\circ} \mathrm{C}$. Solid content was calculated from the dry weight of the coatings. Three measurements were averaged for each type of coating. Dry film thickness was determined by a ZEISS Stemi 305 light microscope and a ZEISS Axiocam ERc 5s camera with $2 \mathrm{X}$ magnification based on the EN ISO 2808 (2007) standard.

\section{Adhesion Test \\ Wood specimens, which had dimensions of $120 \times 70 \times 10 \mathrm{~mm}$, were used for determination of adhesion strength. The wood specimens were measured. Experiments were carried out by taking two measurements from each sample according to the ASTM D 4541 standards. Steel cylinders with a diameter of $20 \mathrm{~mm}$ were attached to the center of the specimens with epoxy resin adhesive and left to condition for 24 hours at $20 \pm 2{ }^{\circ} \mathrm{C}$ and $65 \% \pm 5$ relative humidity for curing the glue.}


Then, the samples were placed under the drawing cylinder of an adhesion resistance measurement instrument (Erichsen Adhesionmaster $525 \mathrm{MC}$ ), the steel cylinders were connected, and tests were carried out at a rate of $0.5 \mathrm{~N} / \mathrm{s}$.

The force value at break was measured on the sensitivity level of $\pm 0.01 \mathrm{~N}$, and the adhesion strength of the samples was calculated using the following equation:

$\rho_{a}=\frac{F}{A}$

$\rho_{\text {a: }}$ Adhesion strength $\left(\mathrm{N} / \mathrm{mm}^{2}\right) ; \mathrm{F}$ : Force at failure $(\mathrm{N})$; A: Application area $\left(\mathrm{mm}^{2}\right)$

\section{Results and Discussions}

Determination of dry-film thickness and microscopic analyzing

The dry-film thickness values of the acrylic-based coatings containing bark extracts (test) and commercial UV absorber (control) on the wood surfaces were determined by light microscopy as given in Table 2 (Grüll, Tscherne, Spitaler \& Forsthuber, 2014). The dry-film thickness values of the coatings containing bark extracts were higher than those of the commercial UV absorber. Scots pine and beech wood have different specific gravity and anatomical structure. Therefore, it was found that the coating penetration was higher and dry film thickness was lower on the scots pine wood surfaces as seen in Fig. 1-2. It is well-known that scots pine wood is much more permeable than beech wood which results in much deeper coating penetration (Ozdemir \& Hiziroglu, 2007; Ozdemir, Bozdogan \& Mengeloglu, 2013; Ozgenc, 2017). Consequently, this situation could cause formation of a thin film on scots pine wood samples. The dry-film thickness values also verified this phenomenon. Meanwhile, dryfilm thickness also had an effect on the service lives of coatings which reduce during aging (Skale, Doleček \& Slemnik, 2008). Previous studies reported that beech wood with or without coating is more durable due to its structural properties against weathering factors in comparison to scots pine (Ozgenc et al., 2012; Ozgenc, 2017).
Table 2. Dry film thickness on the scots pine and beech surfaces coated with acrylic based coatings $(\mu \mathrm{m})$

\begin{tabular}{ccc}
\hline Coating code & Scots pine & Beech \\
\hline A & 45.36 & 71.24 \\
B & 43.73 & 80.47 \\
C & 44.58 & 70.59 \\
D & 52.81 & 68.37 \\
E & 53.73 & 87.96 \\
F & 37.23 & 65.37 \\
\hline
\end{tabular}
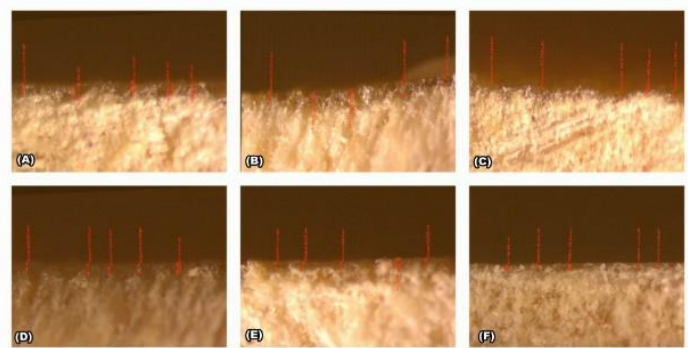

Figure 1. Microscopic image of scots pine surfaces coated with test and control acrylic systems.
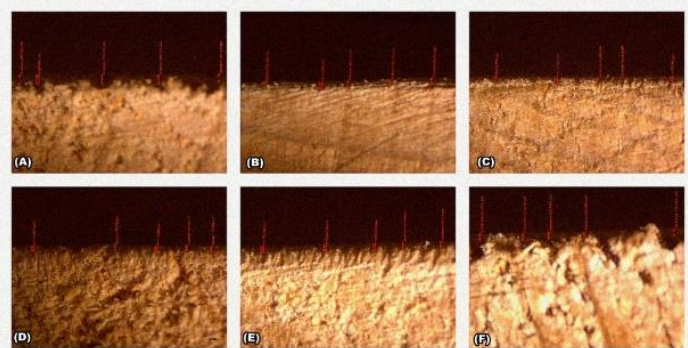

Figure 2. Microscopic image of beech surfaces coated with test and control acrylic systems.

\section{Determination of Solid Content}

The solid content of acrylic based coatings was given in Table 3 .

Table 3. Solid content of acrylic based coatings $(\%)$

\begin{tabular}{cc}
\hline Coating code & Solid content \% \\
\hline A & 38.11 \\
B & 32.09 \\
C & 41.18 \\
D & 42.09 \\
E & 39.27 \\
F & 35.47 \\
\hline
\end{tabular}

As seen, the solid content of coating was similar, except coating B and F. In general, bark extracts had higher solid content as 
compared to coating containing commercial UV absorber.

\section{Adhesion Test}

The adhesion of coating materials to wood and their ability to spread over the substrate surface are primarily controlled by interactions between the surface forces at the interface (Kúdela \& Liptáková, 2006). The adhesion strength of the acrylic-based coating systems containing bark extracts and commercial UV absorber on wood surfaces was shown in Table 4. The adhesion strength of the coatings on the beech wood surface was found to be higher in comparison to scots pine wood, which could have been affected by the thin dry-film thickness. According to previous studies, penetration of coatings into the wood is inversely proportional to dry-film thickness (Kim, 2018). Therefore, the increase in penetration resulted in a thin dry-film thickness, as seen in the scots pine wood samples in this study. These phenomena have affected adhesion strength between wood and coatings negatively (Bardage \& Bjurman, 1998; Bulian \& Graystone, 2009). Meanwhile, Yalcin and Ceylan (2017) reported that bark extractives decrease adhesion strength.

Table 4. Adhesion test values of coating systems $\left(\mathrm{N} / \mathrm{mm}^{2}\right)$

\begin{tabular}{ccc}
\hline $\begin{array}{c}\text { Coating } \\
\text { type }\end{array}$ & Acrylic-beech & $\begin{array}{c}\text { Acrylic-Scots } \\
\text { pine }\end{array}$ \\
\hline A & 2.64 & 1.36 \\
& $(0.46)$ & $(0.19)$ \\
B & 2.35 & 0.45 \\
& $(0.24)$ & $(0.17)$ \\
C & 2.93 & 0.29 \\
& $(0.32)$ & $(0.09)$ \\
D & 2.71 & 0.64 \\
& $(0.88)$ & $(0.16)$ \\
E & 2.71 & 0.19 \\
& $(0.45)$ & $(0.09)$ \\
F & 1.71 & 0.64 \\
& $(0.41)$ & $(0.11)$ \\
\hline
\end{tabular}

Note: The standard deviation values are given in parenthesis.

The application of extracts before coating could change the wood's chemical structure which adversely effects the adhesion strength.
On the contrary, in this study, bark extractives increased adhesion strength, which could have resulted from different application methods. The change in adhesion resistance is mainly due to interactions between polar components of the surface free energy of adjacent phases. The increase in the adhesion of the coating materials during the curing process was accompanied by a decrease in the interface free energy at the interface with wood (Kúdela \&Liptáková, 2006). The change in adhesion strenght depends on the cohesion and adhesion effect between the wood surface and the varnish system. Therefore, factors such as polar structure of the coating system, moisture content of wood material, surface chemistry, application method of varnish (brush, spraying etc.) change the adhesion strenght (Gindl, Reiterer, Sinn \& Stanzl-Tschegg, 2004). In both wood types, the acrylic-based coatings containing fir bark extract (A) provided the highest adhesion strength values. The coatings containing commercial UV absorber had even lower adhesion strength values for both wood species.

\section{Conclusion}

The dry-film thickness and adhesion strength of coatings have an important role in the service life of wooden materials. The importance of dry-film thickness and adhesion strength was particularly highlighted in this study. Many factors influenced dryfilm thickness, including species, permeability and density. It was clearly seen that high permeability reduces adhesion strength as well as dry-film thickness. Scots pine penetrated by more coatings resulted in a thin dry-film thickness. Therefore, the adhesion strength of the coated scots pine wood samples was found to be lower than the coated beech wood samples. Moreover, bark extracts increased dry-film thickness which is important to obtain high adhesion strength. Eventually, these results indicated that bark extractives could be evaluated as natural UV absorbers instead of commercial UV absorbers because they are durable, environmentally friendly, easy to apply and economical. Therefore, waterborne acrylicbased coatings containing bark extractives could be applied on furniture, deck, pergolas, fences, children's play elements, pots, rails 
and sidings. Moreover, utilization of tree barks which are normally recognized as forest waste, can be used for value addition.

\section{Acknowledgment}

This study was supported by Karadeniz Technical University's Scientific Research Project Unit by the project coded FUK 20165294. This study was presented at the International Technological Science and Design Symposium (ITESDES) on 27-29 June 2018 in Giresun, Turkey. We thanks BASF Company to provide coatings chemicals.

\section{References}

ASTM, D. (2002). 4541, Standard Test Method for Pull-Off Strength of Coatings Using Portable Adhesion Testers. Annual Book of ASTM Standards, 1-13.

Bardage, S.L. \& Bjurman, J. (1998). Adhesion of waterborne paints to wood. Journal of Coatings Technology, 70(78), 39-47.

Bulian, F. \& Graystone, J.A. (2009). Wood coatings: Theory and Practice. Oxford: Elsevier.

Decker, C., Masson, F. \& Schwalm, R. (2004). Weathering Resistance of Water-Based UVCured Polyurethane-Acrylate Coatings. Polymer Degradation and Stability, 83, 309320.

EN ISO 2808 (2007) Paints and varnishesdetermination of film thickness.

Evans, P.D.\&Chowdhury M.J. (2010). Photostabilization of wood with higher molecular weight UV absorbers. In 41st Annual Meeting Of The International Research Group On Wood Protection, Biarritz, France.

Feist W.C. \& Hon D.N.-S. (1984). In: Rowell R. M., Ed. "The Chemistry of solid wood", Chapter 11: Chemistry of weathering and protection. advances in chemistry series 207, Washington, Dc: American Chemical- Society.

Feist, W.C. (1990). Weathering performance of painting wood pretreated with water-repellent preservatives. Forest Products Journal, 40(7/8), 21-26.

Gindl M., Reiterer A., Sinn G. \& Stanzl-Tschegg S.E. (2004). Effects of surface ageing on wettability, surface chemistry, and adhesion of wood, Holz als Roh- und Werkstoff, 62 (4), 273-280.

Grüll, G., Tscherne, F., Spitaler, I. \& Forsthuber, B. (2014). Comparison of wood coating durability in natural weathering and artificial weathering using fluorescent UV-lamps and water. European Journal of Wood and Wood Products, 72(3), 367-376.

Kılıç A.\&Hafizoğlu H. (2007). Açık hava koşullarının ağaç malzemenin kimyasal yapısında meydana getirdiği değişimler ve alınacak önlemler. Süleyman Demirel Üniversitesi Orman Fakültesi Dergisi, A(2), 175-183

Kim, Y.S. (2018). Current researches on the protection of exterior wood from weathering, Journal of The Korean Wood Science and Technology, 46(5), 449-470.

Kocaefe, D. \& Saha S. (2012). Comparison of the protection effectiveness of acrylic polyurethane coatings containing bark extracts on three heat-treated North American wood species: Surface Degradation. Applied Surface Science, 258, 5283-5290.

Kúdela J. \& Liptáková E. (2006). Adhesion of coating materials to wood, Journal of Adhesion Science and Technology , 20 (8), 875-895.

Olsson S., Johansson M., Westin M. \& Östmark E. (2012). Grafting of 2-hydroxy-4(2,3epoxypropoxy)-benzophenone and epoxidized soybean oil to wood: Reaction conditions and effects on the color stability of Scots pine. Polymer Degradation and Stability, 97, 17791786.

Ozdemir T., Hiziroglu S. (2007). Evaluation of surface quality and adhesion strength of treated solid wood. Journal of Materials Processing Technology, 186(1-3), 311-314.

Ozdemir T., Bozdogan Ö. \& Mengeloglu F. (2013). Effects of varnish viscosity and film thickness on adhesion strength of coated wood. ProLigno, 9(4), 164-168.

Ozgenc, O., Hiziroglu, S. \& Yildiz, U.C., (2012). Weathering properties of wood species treated with different coating applications. BioResources, 7(4), 4875-4888.

Ozgenc, O. (2017). Weathering performance of a wood surface coated with acrylic resin containing UV absorber. Drewno: prace naukowe, doniesienia, komunikaty, 60.

Pandey, K.K. (2005). A note on the influence of extractives on the photo-discoloration and photo-degradation of wood. Polymer Degradation and Stability, 87, 375-379.

Philip D.E. \& Mohammed J.A. (2010). Chowdhury, photoprotection of wood using polyester-type UV-absorbers derived from the reaction of 2-hydroxy-4(2,3-epoxypropoxy)benzophenone with Dicarboxylic Acid Anhydrides. Journal of Wood Chemistry and Technology, 30(2), 186-204.

Saha, S., Kocaefe, D., Boluk, Y. \& Pichette, A. (2011). Enhancing exterior durability of Jack Pine by photo-stabilization of acrylic 
polyurethane coating using bark extract, Part I: Effect of UV on Color Change and ATR-FTIR analysis. Progress in Organic Coatings, 70, 376-382.

Saha, S., Kocaefe, D., Krause, C., Boluk, Y. \& Pichette, A. (2013). Enhancing exterior durability of Jack Pine by photo-stabilization of acrylic polyurethane coating using bark extract, Part II:Wetting characteristics and fluorescence microscopy analysis. Progress in Organic Coatings, 76, 504-512.

Skale, S., Doleček, V. \& Slemnik, M. (2008). Electrochemical impedance studies of corrosion protected surfaces covered by epoxy polyamide coating systems. Progress in Organic Coatings, 62(4), 387-392.

TAPPI, T. (2012). $257 \mathrm{~cm}-12$. Sampling and preparing wood for analysis. TAPPI Press, Atlanta, GA

TAPPI T. (2007). T264 cm-07. Preparation of wood for chemical analysis. TAPPI Press, Atlanta, GA

Williams, R., S., 2005. "Handbook of wood chemistry and wood composites", Chapter 7: Weathering Of Wood, Forest Products Laboratory, Usda, Forest Service.

Yalcin, M. \& Ceylan, H. (2017). The effects of tannins on adhesion strength and surface roughness of varnished wood after accelerated weathering, Journal of Coatings Technology and Research, 14(1), 185-193.

https://www.ulprospector.com/en/na/Coatings/De tail/479/741631/Tinuvin-400-DW-N (2019). 